ogy to match their own needs and capabilities.

So far, one success story in the effort to replace CFCs seems to be Mexico. There, according to Jorge Corona, the director of ecological studies for the National Chamber of Industrial Transformation, the government took the lead in deciding to phase out CFCs as quickly as developed countries and industry quickly jumped on board. With the coming free trade pact with the United States, Corona said, "it would be foolish to be 10 years behind our trading partners in developing the replacement technology."

Mexico is phasing out CFC aerosols faster than Japan, and it has cut its use of CFCs in foam manufacture by half, said Geno Nardini of Valvulas de Precision. It is still waiting for adequate substitutes for refrigeration and air conditioning uses, he said, but "local companies are preparing themselves so that when they get the okay from the US and Europe, they're ready to go."

Mexican industry has an advantage over that of many developing countries because of close ties with some of the multinational corporations that will be developing the replacement technology, and it intends to use those contacts for "seed help", Nardini said. But it plans to adapt the technology for its own uses and then help other developing countries to make the changeover from CFCs. "Once technology is adapted to one developing country, it is much easier to transfer to another country at the same stage of development," Corona said.

Like the other delegates at the meeting, Corona and Nardini recognize the importance of establishing the CFC replacement campaign as a prototype for the future. "This has helped the whole world study the mechanisms for fighting this sort of problem," $\mathrm{Co}$ rona said. "If we had not had the experience we're having now dealing with CFCs, I don't think the world would be ready for dealing with global warming."

Robert Poo

\title{
NHS launches first strategy
}

\section{London}

MORE than 40 years after its creation, the UK National Health Service (NHS) last week announced its first-ever comprehensive research strategy. Michael Peckham, director of research and development for the NHS since January, says the aim is to "pervade the NHS with research activity". For the first time, each Regional Health Authority (RHA) will have to draw up research plans

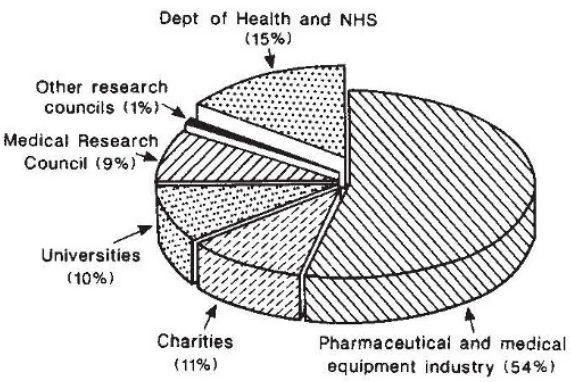

Health research funding in England 1989/90 Source: UK Department of Health.

and show the NHS management that these are being carried out.

Most NHS-funded research projects now are aimed at assessing the effectiveness of different treatment methods. This will be stepped up, says Peckham, to weed out ineffective methods. The NHS will also keep a "weather eye" on fundamental biomedical research, looking for advances that may yield new treatments, he says. But sceptics point out that new and more effective treatments are often more expensive, which may dissuade hospitals from introducing them. Under NHS reforms introduced last month, health authorities can choose to send patients to the hospitals that seem to offer the best value for money. As the health authorities have limited budgets, there are fears that there will be pressure to send patients to hospitals where treatment is cheapest.

A new central NHS research and development committee is to be appointed in the coming months, and will set between six and ten 'priority areas' for NHS research. RHAs will then bid for grants from a central pot of money to support these research areas. This centrally directed fund should ensure that the separate research plans put together by the RHAs fit within the national strategy, says Peckham.

The first job, however, is to find out just how much the NHS now spends on research - a figure now known only approximately. Peckham estimates it to be about $£ 225$ million a year (about 1 per cent of the total NHS budget), but freely admits that NHS research spending has never been calculated accurately. The government plans to increase spending on research to 1.5 per cent of the NHS budget within five years.

Peckham also wants to increase collaboration between the NHS and other British bodies funding medical research. He aims to set up several research liaison groups, to bring together representatives from the NHS, the Medical Research Council, the medical research charities, industry and the universities. Each liaison group will concentrate on a specific health problem, such as cardiovascular disease or mental health. Peckham's model is the UK Coordinating Committee on Cancer Research, run by the Medical Research Council and several of the leading cancer research charities, and widely praised for its role in coordinating British cancer research.

Peckham's appointment to the new post of NHS director for research and development followed criticism from the House of Lords Science and Technology Committee of the low priority given to research in the NHS.

Peter Aldhous

\section{African states invoke origin test to resist ban}

\section{Johannesburg}

SouTH African states are planning to market culled ivory which has had its origin certified using a technique described last year in Nature. In principle, the technique can ensure that ivory does not come from poached elephants and thus protect Africa's elephant population, while still making some ivory available for sale.

Five states (Botswana, Namibia, Zimbabwe, Malawi and Zambia) are concluding plans to establish a Southern African Ivory Marketing Centre (SACIM), which will auction ivory at a market in Gaborone. They hope to persuade the Convention on International Trade in Endangered Species (CITES) to exempt certified ivory from the world ban on trade in this commodity.

When CITES decided in October 1989 to declare a two-year moratorium on the ivory trade, it angered Botswana, South Africa and Zimbabwe, which derive considerable income by exporting ivory culled from their populations of African elephants. The populations in these countries, in which poaching is largely under control, have been growing even while the elephant population across Africa as a whole has been in decline - from about 1.34 million individuals in 1979 to 622,000 today. Botswana, Zimbabwe and Malawi entered immediate reservations to the ban, but these are of little avail so long as importers (particularly Japan, which imported almost half the world's ivory in 1989), observe it. Ivory is currently being stockpiled in South Africa, as culling programmes in the Kruger National Park (which contains most of its elephant population), are con- tinuing. The National Parks Board will lose an estimated R6 million in revenue over the two-year period. Zimbabwe and Botswana have probably suffered considerably higher losses, and are far more strapped for cash.

Until recently, there had been no way of determining whether ivory originated from a country where culling is permitted or from one where elephants are in danger of extinction. But the authors of two recent papers in Nature $(346,744-749 ; 1990)$ provided a solution: by measuring the isotope ratios of carbon, nitrogen and strontium in samples of ivory and bone, different isotopic "signatures" can be determined for elephants from different localities.

Botswana's deputy director of Wildlife, Nigel Hunter, says that part of SACIM's revenue will be channelled back into elephant conservation programmes.

Michael Cherry 